\title{
Nursery growth and rhizobia symbiosis of scandent Leguminosae species native to the Amazon region
}

\author{
Fatima Maria de Souza MOREIRA ${ }^{1}$; Katia Pereira COELHO $^{1,2^{*}}$; Paula Rose de Almeida RIBEIRO ${ }^{3}$; \\ Amanda Azarias GUIMARÃES 3 \\ ${ }^{1}$ Universidade Federal de Lavras - Departamento de Ciência do Solo, Lavras, Minas Gerais, Brazil. \\ ¿Universidade Federal de Lavras - Programa de Pós-Graduação em Microbiologia Agrícola, Lavras, Minas Gerais, Brazil. \\ ${ }^{3}$ Universidade Federal de Lavras - Programa de Pós-Graduação em Ciência do Solo, Minas Gerais, Brazil. \\ *Corresponding author: katiapc2004@yahoo.com.br
}

\begin{abstract}
A great number of species and individuals of scandent legumes establishing symbiosis with nitrogen fixing bacteria occurs in the Amazon Forest. These symbiosis probably play an important role in contributing to nitrogen incorporation in this ecossystem. The objectives of this study were to evaluate the growth of eight species of scandent legumes in five nursery substrates; to compare nodulation with rhizobia strains introduced or native to these substrates; and to characterize phenotypically and genetically these rhizobia. The experiment was carried out in a completely randomized design with five replications. Five to seven months after seedling emergency, according to the legume species, growth and nodulation parameters were determined. Rhizobia identification of strains was carried out by $16 \mathrm{~S}$ rRNA gene partial sequencing. The survival of seedlings after the transplanting varied from 93 to $98 \%$, in Ultisol (Argissolo in Brazilian classification), collected in primary forest, and fertilized with all nutrients, except nitrogen (ULTfert); and in a clay and sand mixture, in a ratio 3:2 (CONV), respectively. Species with height superior to $30 \mathrm{~cm}$, in general, grew better in substrates with higher fertility: ULTfert and Humic Gley soil (HG). Seven out of the eight species were able to nodulate. The percentage of nodulation per substrate was: SAND, washed sand with mixed inoculum of 100 rhizobia strains plus fertilization (100), HG (80), CONV (100), ULT, A-horizon of red-yellow Ultisol collected in the Ducke Forest Reserve (Manaus) (44), and ULTfert (55\%). Bradyrbizobium spp. were isolated from nodules of all species and substrates. Burkolderia fungorum was isolated from Dalbergia inundata. For Dalbergia riedelli and Dalbergia inundata, this is the first report on the identification of symbiotic strains. Scandent legumes present high survival of seedlings in nursery, and develop better in substrates with higher fertility, and generally present symbiosis with Bradyrhizobium.
\end{abstract}

KEYWORDS: Forest species, lianas, biological nitrogen fixation, Bradyrhizobium.

\section{Crescimento e simbiose com rizóbios em casa de vegetação de espécies de Leguminosae escandentes nativas da região Amazônica}

\section{RESUMO}

Um grande número de espécies e indivíduos de leguminosas escandentes estabelecendo simbiose com bactérias fixadoras de nitrogênio ocorrem na floresta Amazônica. Estas simbioses provavelmente desempenham importante papel, contribuindo para incorporaçáo de nitrogênio neste ecossistema. Os objetivos deste trabalho foram avaliar o crescimento de oito espécies de leguminosas escandentes em cinco substratos no viveiro; comparar a nodulaçáo com as estirpes de rizóbio introduzidas ou nativas destes substratos; e caracterizar esses rizóbios fenotípica e geneticamente. O experimento foi conduzido em delineamento inteiramente casualizado com cinco repetiçóes. Cinco a sete meses após a emergência das mudas parâmetros de crescimento e nodulação foram determinados. A identificação das estirpes de rizóbios foi feita pelo sequenciamento parcial do gene 16S rRNA. A sobrevivência das mudas após o transplante variou de 93 a 98\%, em um Argissolo (Ultisol de acordo com a classificação da USDA), coletado em floresta primária e adubado com todos os nutrientes, exceto nitrogênio (ULTfert), e na mistura argila e areia, na proporção 3:2 (CONV), respectivamente. Espécies que apresentaram altura superior a $30 \mathrm{~cm}$, no geral, cresceram melhor nos substratos de maior fertilidade: ULTfert e solo Glei Húmico (GH). Das oito espécies estudadas, sete nodularam. A porcentagem de nodulação por substrato foi: AREIA, areia lavada com inóculo misto de 100 estirpes de rizóbio mais adubação (100), GH (80), CONV (100), ULT, horizonte A de Argissolo vermelho-amarelo coletado na Reserva Florestal Ducke (Manaus) (44) e ULTfert (55\%). Bradyrhizobium spp. foram isolados de nódulos de todas as espécies e substratos. Burkolderia fungorum foi isolada de Dalbergia inundata. Este é o primeiro relato de identificação de estirpes simbióticas para Dalbergia riedelli e Dalbergia inundata. Leguminosas escandentes apresentaram alta sobrevivência de mudas em casa de vegetação e desenvolveram-se melhor em substratos com maior fertilidade e, geralmente, estabeleceram simbiose com Bradyrhizobium.

PALAVRAS-CHAVE: Espécies florestais, lianas, fixação biológica de nitrogênio, Bradyrhizobium. 


\section{INTRODUCTION}

Scandent legumes (lianas or vines) constitute an abundant and diverse group of plants found in forests, especially tropical forests. In the Amazon, scandent legumes, along with the tree legume species, are predominant in number of species and individuals. Scandent legumes and shrubs under natural conditions in the forest differ in relation to biomass production, and may be of small to large size (Ducke 1949).

The economic and ecological role of scandent legumes, both in natural and managed systems, is not fully elucidated, despite the fact that the economic importance of some species, such as Deguelia negrensis, Dalbergia riparia and Dalbergia inundata have been highlighted in phytochemistry, especially with respect to the presence of flavonoids (Braz Filho et al. 1973; Ribeiro et al. 1987; Zoghbi et al. 1992). Moreover, some scandent species may establish symbiosis with nitrogen-fixing bacteria, commonly known as rhizobia (Moreira et al. 1992; 1993; 1998). Biological nitrogen-fixation is an important strategy for the establishment of these legumes in nitrogen-deficient soils (Franco and Faria 1997). Surveys involving capture, characterization and identification of rhizobia strains in symbiosis with little studied plant species, such as scandent legumes, may increase the chance of obtaining novel strains that are useful for various ecological and economic purposes. These novel strains can improve culture collections, as well as can be an important source of novel species and genetic resources with biotechnological potential.

Some studies have discussed the role of scandent legumes in regeneration in treefall gaps in forests (Grauel and Putz 2004; Schnitzer et al. 2004). There is positive correlation between abundance and diversity of pioneer trees and scandent legumes (Schnitzer et al. 2000), which may facilitate the process of ecological succession, and speed recovery from disturbances that occur within a forest. However, studies on the characteristics of legumes growth under controlled conditions are practically non-existent, as well as studies on nodulation capacity, and phenotypic and genetic characterization of rhizobia strains symbiotic with these legumes (Moreira et al. 1993; 1998). Different substrates can be used in nursery conditions. However, the best substrates are those using soils of the focused region because of the native rhizobia that they contain, which can be trapped and studied. (Moreira et al. 1993; Moreira 1995; 1997). The objective of this study was to evaluate the growth of eight species of scandent legumes in five nursery substrates; to compare nodulation of species nodulating with rhizobia strains introduced or native to these substrates; and to characterize phenotypic and genetically these rhizobia.

\section{MATERIALS AND METHODS}

\section{Collection of botanical material and seeds}

This work was inserted in a large survey project of nodulating legumes in the Amazon region, where the collection of material occurred concomitantly with other legumes. Detailed information on data collection (location and date), and initial morphology of seedlings (IMS) of all studied species may be obtained in Silva et al. (1988), Moreira et al. (1992), and Moreira and Moreira (1996). Botanical material and seeds of scandent legumes species were collected in natural habitats, in the cities of Manaus and Manacapuru, in the Anavilhanas Archipelago, and in the state of Acre. Species identification was carried out by comparison with exsiccatae of the Herbarium of the Department of Botany of the National Institute of Amazonian Research (INPA). Most of the collected botanical material was incorporated to the herbarium collection, where it received a registration number. The botanical material not incorporated to the herbarium collection remained with the collection number. The studied species with their respective herbarium number or collection number were: Entada polystachya var. polyphylla (Benth.) Barneby (F504); Dalbergia inundata Spruce ex Benth. (133637); Dalbergia riedelii (Radlk) Sandwith. (138783); Deguelia negrensis (Benth.) Taub. (sin. Derris negrensis Benth.) (138790); Machaerium quinata (Aubl.) Sandwith (138792); and Mimosa sp. (156534). Two species with different provenances were also studied: Machaerium inundatum (provenance 1- 124718; provenance 2- 138794), and Dalbergia riparia (provenance 1- 133857; provenance 2-138785).

\section{Nursery Experiment}

The experiment was carried out in Manaus. Seeds were placed to germinate in boxes containing washed and sterilized sand. Treatments to break seed dormancy were not applied. When the first true leaves were formed, seedlings were transplanted to polyethylene bags containing $2 \mathrm{~kg}$ of the following substrates: SAND - washed sand with mixed inoculum of 100 rhizobia strains plus fertilization (per bag) of $3 \mathrm{ml} \mathrm{CaSO}_{4} \mathrm{M}, 4 \mathrm{ml} \mathrm{K}_{2} \mathrm{SO}_{4} \mathrm{M}, 2 \mathrm{ml}$ $\mathrm{Na}_{2} \mathrm{HPO}_{4} \mathrm{M}, 4 \mathrm{ml} \mathrm{MgSO}{ }_{4} \mathrm{M}$ and $1 \mathrm{ml}$ of micronutrient solution (per liter: $2.86 \mathrm{~g} \mathrm{H}_{3} \mathrm{BO}_{3} ; 1.81 \mathrm{~g} \mathrm{MnCl}_{2} ; 0.22 \mathrm{~g} \mathrm{ZnSO}_{4} .7 \mathrm{H}_{2} \mathrm{O} ; 0.8$ $\mathrm{g} \mathrm{CuSO}_{4} .5 \mathrm{H}_{2} \mathrm{O} ; 0.02 \mathrm{~g} \mathrm{MoO}_{3} .2 \mathrm{H}_{2} \mathrm{O}$; and $\left.0.02 \mathrm{~g} \mathrm{CoCl}_{2}\right)$. Other substrates were HG - A- horizon of Humic Gley soil collected in the floodplain of Solimóes River; CONV - Conventional nursery substrate, consisting of a clay and sand mixture, in a ratio 3:2 (v:v); ULT - A-horizon of red-yellow Ultisol (Argissolo according to the Brazilian classification) collected in the Ducke Forest Reserve (Manaus); and ULTfert - fertilized ULT substrate (per bag) with: $3 \mathrm{~g}$ dolomitic lime, $0.2 \mathrm{~g}$ superphosphate, $0.2 \mathrm{~g}$ phosphate rock (Maranhão Bauxite), $4 \mathrm{~mL} \mathrm{~K}_{2} \mathrm{SO}_{4} \mathrm{M}$, and $1 \mathrm{ml}$ micronutrients solution. Chemical characteristics of $\mathrm{HG}, \mathrm{CONV}$ and ULT substrates were, respectively, $\mathrm{pH}$ in water: 4.9, 5.2 and 4.3; $\mathrm{Al}\left(\mathrm{mmol} \mathrm{kg}_{\mathrm{c}}^{-1}\right): 5,1,14 ; \mathrm{Ca}+\mathrm{Mg}\left(\mathrm{mmol} \mathrm{kg}_{\mathrm{c}}^{-1}\right): 136,60$ and 3; $\mathrm{P}\left(\mathrm{mg} \mathrm{kg}^{-1}\right): 75,2$ and 2; and $\mathrm{K}\left(\mathrm{mg} \mathrm{kg}^{-1}\right): 59,17$ and 
23. The rhizobia strains used in the inoculum applied to SAND were derived from isolation carried out using nodules from Amazon legumes, whose characteristics are shown in Moreira et al. (1993). Each strain was grown separately and then mixed in the same proportion. Three seedlings were transplanted per bag. Depending on the species, up to 15 plants per substrate were transplanted. After transplanting, seedlings were placed in nursery under shade coverage (50\%). Fifteen days after transplanting, thinning was carried out, remaining only one plant per bag. At this time, the percentage of seedling survival after transplanting was measured. The experiment was carried out in a completely randomized design with 5 replications (five bags, each bag with one plant) per treatment (substrate). Surplus replications were discarded. Irrigation was carried out daily, once or twice depending on climatic conditions. Because there was a large amount of evaluations, it would be impossible to evaluate all the parameters of all species at the same time. Therefore, height was measured for all species at the same age (five months), in order that the growth of all species could be compared. Thus, five to seven months after emergency, depending on the species, the following parameters were determined: height (measured with a rule from the base of the stem to the apical bud), stem diameter (measured with a caliper rule), shoot and root dry matter, nodule number (by counting), and nodule dry matter. Shoot, root, and nodule samples were weighted in a three digit balance. To all species, it was assigned a growing class value, in relation to height measured in the HG substrate, registered at five months of development, as follows: Class 1: less than or equal to 10 cm; Class 2: 10.1 to $30 \mathrm{~cm}$; Class 3: greater than $30.1 \mathrm{~cm}$. HG was chosen as reference because most species grew better in this substrate. Data were tested for normality using the Shapiro-Wilk test. All the analyzed parameters were transformed by square root of $(x+1)$, to meet the statistical assumptions. Treatment means were compared by the Scott-Knott test at 5\% probability, using the Sisvar 5.3 statistical analysis software (Ferreira 2011).

\section{Nodules collection, and isolation and phenotypic characterization of rhizobia strains}

Of each nodulating species, in each substrate, we selected nodules that had acetylene reduction activity above $20 \mathrm{nmol} \mathrm{C}_{2} \mathrm{H}_{4}$ $\mathrm{h}^{-1}$ per nodule (Dilworth 1966), which indicates the presence of nitrogenase for bacteria isolation and characterization. For isolation, nodules surface disinfection was carried out using alcohol (95\%), followed by immersion in $0,1 \% \mathrm{HgCl}_{2}$ and $0,5 \% \mathrm{HCl}$ solution for 1 to 3 minutes, depending on the nodule size. Finally, repeated washings in sterile water were carried out. The nodules were subsequently macerated in plates containing 79 culture medium (Fred and Waksman 1928), also known as YMA (Vincent 1970), with acid (5.0) and neutral (7.0) pH. This medium contained bromothymol blue. The material was spread in streaks to obtain single colonies, and the bacteria were left to grow at $28^{\circ} \mathrm{C}$. Pure colonies were harvested and characterized morphologically, according to Moreira et al. (1993). Strains isolated in the medium with $\mathrm{pH} 5.0$ and $\mathrm{pH}$ 7.0, respectively received the letter $\mathrm{A}$ and $\mathrm{B}$ after the identification code. Twentynine strains isolated from nodules of the studied legumes were characterized according to: time of appearance of isolated colonies: (fast: 1-3 days, intermediate: 4-5 days, slow: 6-10 days; and very slow: above 10 days) and $\mathrm{pH}$ alteration (acid, alkaline or neutral). A binary matrix was constructed with this cultural characteristics, and strains were clustered by the UPGMA method (Unweighted Pair Group Method with Arithmetic Mean), based on the Jaccard index $(\mathrm{J})$, in order to generate a phenotypic similarity dendrogram. Based on the results of this characterization, 17 strains representative of each of the phenotypic clusters obtained, considering those with similarity of approximately $45 \%$, were selected for 16S rRNA gene partial sequencing.

\section{DNA extraction and 16S rRNA gene partial sequencing}

DNA extraction was carried out by the Bacterial Genomic DNA kit ZR Fungal/Bacterial DNA MiniPrep ${ }^{\mathrm{TM}}$ of Zymo research, and for some strains, whose extraction by the kit was not efficient, the alkaline lysis method was used (Niemann $e t$ al. 1997). $16 \mathrm{~S} \mathrm{rRNA}$ gene amplification was carried out using $5 \mu \mathrm{L}$ DNA, $5 \mu \mathrm{L}$ buffer $10 \mathrm{X} \mathrm{KCl}, 4 \mu \mathrm{L} \mathrm{MgCl}_{2}(2,5 \mathrm{mM})$, $5 \mu \mathrm{LdNTP}$ Mix $(2 \mathrm{mM}), 1 \mu \mathrm{L}$ of each primer, $27 \mathrm{~F}$ and $1492 \mathrm{R}$ $10 \mathrm{mmol} \mathrm{L}^{-1}$ (Lane 1991), $0.4 \mathrm{uL}$ Taq DNA polymerase $\left(5 \mathrm{U} \mu \mathrm{L}^{-1}\right)$, and sterile Milli-Q water for reaction with total volume of $50 \mu \mathrm{L}$. Amplification reaction was carried out in the Eppendorf Mastercycler ${ }^{\circ}$ thermocycler, in the following conditions: initial denaturation (at $94^{\circ} \mathrm{C}$, for 5 minutes), 35 denaturation cycles (at $94^{\circ} \mathrm{C}$, for 40 seconds), annealing (at $55^{\circ} \mathrm{C}$, for 40 seconds), extension (at $72^{\circ} \mathrm{C}$, for 1 minute and 30 seconds), and final extension (at $72{ }^{\circ} \mathrm{C}$, for 7 minutes). The amplified products were separated on agarose gel $1 \%$ with the addition of SYBR Safe dye (Invitrogen), and visualized under UV light. A $1 \mathrm{~Kb}$ marker (SmartLadder-Eurogentec) was added to the gel to check the quality of the bands obtained and to estimate the length of the amplified products. PCR products were sent to the Macrogen Laboratory (Korea) for sequencing. The quality of the obtained sequences was verified using the BioNumerics 7.1 software (Applied Maths, Austin, TX, USA), and compared to the GenBank database (National Center for Biotechnology Information). Sequences obtained in this study were deposited in GenBank under the accession numbers KT826553 to KT826569.

\section{RESULTS}

\section{Seedlings growth in nurseries}

Of the 577 individuals transplanted to the different nursery substrates, $95 \%$ survived the transplanting. Survival percentages found for SAND, HG, CONV, ULT and ULTfert substrates 
were: 94, 96, 98, 96 and 93\%, respectively. Machaerium quinata had the lowest survival percentage (69\%).

The studied scandent legumes presented different growth classes with respect to height (Table 1). Mimosa sp., Dalbergia inundata, Dalbergia riedelii, Dalbergia riparia (provenance 2), and Machaerium inundatum (provenances 1 e 2) were the highest (up to $30.1 \mathrm{~cm}$ ), and Machaerium quinata was the smallest (up to $10 \mathrm{~cm}$ ).

In general for height and diameter, there was difference ( $\mathrm{p}$ $<0.05$ ) among substrates for Mimosa sp., Dalbergia inundata, Dalbergia riparia (provenance 1 e 2) and Machaerium inundatum (provenances 1 e 2), with higher values observed in HG and ULTfert substrates (Table 1). Deguelia negrensis presented difference $(\mathrm{p}<0.05)$ for ULT substrate only for height.

For shoot and root dry matter, there was significant differences ( $\mathrm{p}<0.05)$ among the substrates for Mimosa sp., Dalbergia inundata, Dalbergia riparia (provenance 2), and Machaerium inundatum (provenance 2), with higher values for HG and ULTfert substrates (Table 2). Species that produced higher amounts of shoot dry matter were Dalbergia riparia (provenance 2), in HG substrate, and Mimosa sp., in ULTfert substrate. Entada polystachya showed high root dry matter (p $<0.05$ ) for HG, ULT and ULTfert substrates. The results obtained for the root/shoot ratio showed a large variation among species: between 0.19 and 2.3. However, differences among substrates ( $\mathrm{p}$
$<0.05)$ were observed only for Dalbergia inundata, with higher value in CONV substrate (Table 2).

For nodule number and nodule dry matter, there was significant difference $(\mathrm{p}<0.05)$ among the substrates for Dalbergia inundata, Dalbergia riedelii, Dalbergia riparia (provenance 2 ) and Machaerium inundatum (provenance 1 e 2) (Table 3). The highest values were observed for SAND, HG and CONV substrates. ULT and ULTfert had high number of species with absence of nodulation (Deguelia negrensis; Machaerium quinata; Dalbergia riparia (provenance 1 e 2); Machaerium inundatum (provenance 1), and Machaerium quinata; and Deguelia negrensis).

All species nodulated in the nursery, with the exception of Mimosa sp. The nodulation percentages of species in the substrates were: SAND (100), HG (78), CONV (100), ULT (44), and ULTfert (55).

\section{S rRNA gene partial sequencing}

The identification and the number of strains by genera were: Bradyrhizobium (13) Brevibacillus (two), and one in each of the genera Burkolderia and Enterobacter (Table 4). Similarity between the studied strains and the GenBank strains varied between 99 and $100 \%$. The non-nodulating genera, Brevibacillus and Enterobacter, were isolated only from nodules of Dalbergia inundata, Dalbergia riedelii and Dalbergia riparia.

Table 1. Mean values for plant height and stem diameter of the scandent legume species native to the Amazon, after growth in five substrates in nursery . SAND, washed sand with mixed inoculum of 100 rhizobia strains plus fertilization; HG, A-horizon of Humic Gley soil collected in the floodplain of Solimões River; CONV, conventional nursery substrate, consisting of a clay and sand mixture, in a ratio 3:2 (v:v); ULT, A-horizon of red-yellow Ultisol collected in the Ducke Forest Reserve (Manaus); and ULTfert, fertilized ULT substrate.

\begin{tabular}{|c|c|c|c|c|c|c|c|c|c|c|c|c|}
\hline \multirow{2}{*}{$\begin{array}{l}\text { Subfamily/Species } \\
\text { (Provenance) }\end{array}$} & \multirow{2}{*}{$\begin{array}{l}\text { Growth } \\
\text { class }^{(1)}\end{array}$} & \multirow{2}{*}{$\begin{array}{l}\text { Seedlings age } \\
\text { (months) }\end{array}$} & \multicolumn{5}{|c|}{ Height (cm) } & \multicolumn{5}{|c|}{ Stem diameter $(\mathrm{cm})$} \\
\hline & & & SAND & $H G$ & CONV & ULT & ULTfert & SAND & $H G$ & CONV & ULT & ULTfert \\
\hline \multicolumn{13}{|l|}{ Mimosoidae } \\
\hline Entada polystachya & 2 & 5 & $16.8 \mathrm{a}^{(2)}$ & $26.4 \mathrm{a}$ & $19.0 \mathrm{a}$ & $21.0 \mathrm{a}$ & $23.8 \mathrm{a}$ & $1.9 a$ & $2.4 \mathrm{a}$ & $2.2 \mathrm{a}$ & $2.1 \mathrm{a}$ & $2.5 a$ \\
\hline Mimosa sp. & 3 & 6 & $13.0 \mathrm{~d}$ & $43.5 b$ & $24.4 \mathrm{c}$ & $34.6 \mathrm{~b}$ & $110.2 \mathrm{a}$ & $1.4 d$ & $3.7 \mathrm{~b}$ & $2.4 \mathrm{c}$ & $2.3 \mathrm{c}$ & $6.5 a$ \\
\hline \multicolumn{13}{|l|}{ Papilionoidae } \\
\hline Dalbergia inundata & 3 & 7 & $25.4 \mathrm{C}$ & $60.2 \mathrm{a}$ & $17.4 \mathrm{c}$ & $41.2 \mathrm{~b}$ & $69.0 \mathrm{a}$ & $3.6 \mathrm{c}$ & $6.7 a$ & $3.5 \mathrm{c}$ & $5.3 b$ & $6.5 a$ \\
\hline Dalbergia riedelii & 3 & 6 & $30.4 a$ & $44.0 \mathrm{a}$ & $31.6 a$ & $40.8 \mathrm{a}$ & $37.6 \mathrm{a}$ & $4.0 \mathrm{a}$ & $4.7 \mathrm{a}$ & $4.3 a$ & $4.6 a$ & $4.9 a$ \\
\hline Dalbergia riparia (1) & 2 & 6.5 & $29.7 a$ & $46.5 a$ & $13.5 a$ & $8.0 \mathrm{a}$ & $19.0 \mathrm{a}$ & $0.21 b$ & $1.35 \mathrm{a}$ & $0.38 b$ & $0.25 b$ & $0.45 b$ \\
\hline Dalbergia riparia (2) & 3 & 6 & $16.0 \mathrm{c}$ & $65.0 \mathrm{a}$ & $16.8 \mathrm{c}$ & $45.8 b$ & $45.4 b$ & $3.6 \mathrm{c}$ & $7.6 a$ & $3.8 \mathrm{C}$ & $4.3 \mathrm{c}$ & $5.4 b$ \\
\hline Deguelia negrensis & 2 & 6 & $12.6 b$ & $14.2 b$ & $13.6 b$ & $33.0 \mathrm{a}$ & $13.0 \mathrm{~b}$ & $2.5 \mathrm{a}$ & $2.8 \mathrm{a}$ & $2.4 \mathrm{a}$ & $3.4 a$ & $2.8 \mathrm{a}$ \\
\hline Machaerium inundatum (1) & 3 & 6.5 & $61.6 b$ & $270.4 a$ & $224.2 a$ & $69.6 b$ & $151.6 \mathrm{~b}$ & $0.79 \mathrm{~b}$ & $1.35 \mathrm{a}$ & $1.14 \mathrm{a}$ & $0.75 b$ & $1.14 a$ \\
\hline Machaerium inundatum (2) & 3 & 6 & $34.6 \mathrm{~b}$ & $59.0 \mathrm{a}$ & $34.2 b$ & $39.2 b$ & $45.6 \mathrm{~b}$ & $6.4 a$ & $6.5 a$ & $4.8 b$ & $5.0 \mathrm{~b}$ & $6.4 \mathrm{a}$ \\
\hline Machaerium quinata & 1 & 6 & $7.8 \mathrm{a}$ & $13.6 \mathrm{a}$ & $10.0 \mathrm{a}$ & $9.4 a$ & $9.6 \mathrm{a}$ & $2.3 \mathrm{a}$ & $3.3 \mathrm{a}$ & $2.7 \mathrm{a}$ & $2.6 a$ & $2.7 \mathrm{a}$ \\
\hline
\end{tabular}

\footnotetext{
(1) Measured at five months in HG substrate. (2) Means of five plants. Means with the same letter, in the same line, do not significantly differ, according to the Skott-Knott test, at $5 \%$.
} 
Table 2. Mean values for shoot and root dry matter per plant, and root/shoot ratio of the scandent legume species native from Amazônia, after growth in five substrates in nursery. SAND, washed sand with mixed inoculum of 100 rhizobia strains plus fertilization; HG, A- horizon of Humic Gley soil collected in the floodplain of Solimões River; CONV, Conventional substrate of nursery, consisting of a clay and sand mixture, in a ratio 3:2 (v:v); ULT, A-horizon of red-yellow Ultisol collected in the DuckeForest Reserve (Manaus); and ULTfert, fertilized ULT substrate.

\begin{tabular}{|c|c|c|c|c|c|c|c|c|c|c|c|c|c|c|c|}
\hline \multirow{2}{*}{$\begin{array}{l}\text { Subfamily/Species } \\
\text { (Provenance) }\end{array}$} & \multicolumn{5}{|c|}{ Shoot dry matter (g) } & \multicolumn{5}{|c|}{ Root dry matter (g) } & \multicolumn{5}{|c|}{$\mathrm{R} / \mathrm{S}^{(1)}$ ratio } \\
\hline & SAND & $H G$ & CONV & ULT & ULTfert & SAND & $\mathrm{HG}$ & CONV & ULT & ULTfert & SAND & $\mathrm{HG}$ & CONV & ULT & ULTfert \\
\hline \multicolumn{16}{|l|}{ Mimosoidae } \\
\hline Entada polystachya & $0.61 a^{(2)}$ & $1.29 a$ & $0.67 a$ & $1.01 \mathrm{a}$ & $1.23 a$ & $0.72 b$ & $2.97 a$ & $1.01 b$ & $2.19 a$ & $2.30 \mathrm{a}$ & $1.18 \mathrm{a}$ & $2.30 \mathrm{a}$ & $1.49 a$ & $2.17 a$ & $1.87 \mathrm{a}$ \\
\hline Mimosa sp. & $0.25 b$ & $1.83 b$ & $0.91 b$ & $1.27 \mathrm{~b}$ & $12.12 \mathrm{a}$ & $0.07 \mathrm{~b}$ & $0.56 b$ & $0.22 b$ & $0.24 b$ & $2.25 \mathrm{a}$ & $0.28 \mathrm{a}$ & $0.31 \mathrm{a}$ & $0.24 a$ & $0.19 a$ & $0.19 a$ \\
\hline \multicolumn{16}{|l|}{ Papilionoidae } \\
\hline Dalbergia inundata & $0.78 c$ & $4.35 a$ & $0.43 c$ & $2.52 b$ & $5.62 \mathrm{a}$ & $0.55 c$ & $2.71 \mathrm{a}$ & $0.55 \mathrm{c}$ & $1.35 b$ & $2.20 \mathrm{a}$ & $0.67 b$ & $0.62 b$ & $1.28 \mathrm{a}$ & $0.54 b$ & $0.38 \mathrm{~b}$ \\
\hline Dalbergia riedelii & $1.40 \mathrm{a}$ & $3.34 a$ & $2.08 a$ & $3.04 a$ & $3.07 a$ & $0.94 a$ & $1.68 \mathrm{a}$ & $1.36 \mathrm{a}$ & $2.0 \mathrm{a}$ & $1.88 \mathrm{a}$ & $0.67 a$ & $0.50 \mathrm{a}$ & $0.65 a$ & $0.66 \mathrm{a}$ & $0.61 \mathrm{a}$ \\
\hline Dalbergia riparia (2) & $0.74 \mathrm{c}$ & $9.04 a$ & $0.70 \mathrm{c}$ & $2.02 b$ & $3.66 b$ & $0.49 \mathrm{~b}$ & $4.12 \mathrm{a}$ & $0.54 b$ & $0.94 b$ & $1.36 \mathrm{a}$ & $0.66 a$ & $0.46 a$ & $0.77 a$ & $0.46 a$ & $0.37 a$ \\
\hline Deguelia negrensis & $0.41 \mathrm{a}$ & $0.71 \mathrm{a}$ & $0.54 a$ & $0.51 a$ & $1.11 \mathrm{a}$ & $0.27 a$ & $0.21 a$ & $0.31 a$ & $0.17 a$ & $0.5 \mathrm{a}$ & $0.66 a$ & $0.3 a$ & $0.57 a$ & $0.33 a$ & $0.45 a$ \\
\hline $\begin{array}{l}\text { Machaerium } \\
\text { inundatum (2) }\end{array}$ & $3.55 b$ & $5.62 \mathrm{a}$ & $2.49 b$ & $2.91 b$ & $5.15 a$ & $1.86 \mathrm{~b}$ & $2.85 a$ & $1.32 b$ & $2.0 \mathrm{~b}$ & $1.89 \mathrm{~b}$ & $0.52 a$ & $0.51 \mathrm{a}$ & $0.53 a$ & $0.69 a$ & $0.37 a$ \\
\hline Machaerium quinata & $0.24 a$ & $1.04 a$ & $0.51 \mathrm{a}$ & $0.45 a$ & $0.51 \mathrm{a}$ & $0.29 a$ & $0.44 a$ & $0.43 a$ & $0.37 a$ & $0.21 \mathrm{a}$ & $1.21 \mathrm{a}$ & $0.42 \mathrm{a}$ & $0.84 a$ & $0.82 \mathrm{a}$ & $0.41 \mathrm{a}$ \\
\hline
\end{tabular}

(1) root/shoot ratio. (2) Means of five plants. Means with the same letter in the same line do not significantly differ, according to the Skott-Knott test, at $5 \%$

Table 3. Mean values for nodule number and nodule dry matter per plant of the scandent legume species native from Amazônia, after growth in five substrates in nursery. SAND, washed sand with mixed inoculum of 100 rhizobia strains plus fertilization; HG, A-horizon of Humic Gley soil collected in the floodplain of Solimões River; CONV, Conventional substrate of nursery, consisting of a clay and sand mixture, in a ratio 3:2 (v:v); ULT, A-horizon of red-yellow Ultisol collected in the DuckeForest Reserve (Manaus); and ULTfert, fertilized ULT substrate.

\begin{tabular}{|c|c|c|c|c|c|c|c|c|c|c|c|}
\hline \multirow{2}{*}{ Subfamily } & \multirow{2}{*}{ Species (Provenance) } & \multicolumn{5}{|c|}{ Nodule number } & \multicolumn{5}{|c|}{ Nodule dry matter (mg) } \\
\hline & & SAND & $H G$ & CONV & ULT & ULTfert & SAND & $H G$ & CONV & ULT & ULTfert \\
\hline Mimosoidae & Entada polystachya & $5.8 \mathrm{a}^{(1)}$ & $2.6 a$ & $2.8 \mathrm{a}$ & $1.6 \mathrm{a}$ & $3.2 \mathrm{a}$ & $15.0 \mathrm{a}$ & $10.0 \mathrm{a}$ & $4.0 \mathrm{a}$ & $3.0 \mathrm{a}$ & $25.0 \mathrm{a}$ \\
\hline \multirow{10}{*}{ Papilionoidae } & Dalbergia inundata & $37.2 \mathrm{a}$ & $42.0 \mathrm{a}$ & $48.0 \mathrm{a}$ & $1.0 \mathrm{~b}$ & $16.8 b$ & $23.0 \mathrm{a}$ & $30.0 \mathrm{a}$ & $35.0 \mathrm{a}$ & $3.0 \mathrm{~b}$ & $9.0 \mathrm{~b}$ \\
\hline & Dalbergia riedelii & $16.2 b$ & $60.0 \mathrm{a}$ & $16.2 b$ & $11.2 b$ & $20.0 \mathrm{~b}$ & $47.0 \mathrm{~b}$ & $181.0 \mathrm{a}$ & $35.0 \mathrm{~b}$ & $36.0 \mathrm{~b}$ & $65.0 \mathrm{~b}$ \\
\hline & Dalbergia riparia (1) & $2.0 \mathrm{a}$ & $1.5 \mathrm{a}$ & $1.5 \mathrm{a}$ & $0 \mathrm{a}$ & $0 \mathrm{a}$ & $2.0 \mathrm{a}$ & $4.0 \mathrm{a}$ & $2.0 \mathrm{a}$ & $0 \mathrm{a}$ & $0 \mathrm{a}$ \\
\hline & Dalbergia riparia (2) & $22.0 \mathrm{~b}$ & $55.0 \mathrm{a}$ & $4.6 \mathrm{c}$ & $0 c$ & $0 c$ & $14.0 \mathrm{~b}$ & $55.0 \mathrm{a}$ & $6.0 \mathrm{~b}$ & $0 b$ & ob \\
\hline & Deguelia negrensis & $7.8 \mathrm{a}$ & $0 \mathrm{a}$ & $4.2 \mathrm{a}$ & $0 \mathrm{a}$ & $7.0 \mathrm{a}$ & $16.0 \mathrm{a}$ & $0 \mathrm{a}$ & $8.0 \mathrm{a}$ & $0 \mathrm{a}$ & $15.0 \mathrm{a}$ \\
\hline & Machaerium inundatum (1) & $30.8 \mathrm{a}$ & $10.8 \mathrm{~b}$ & $61.4 a$ & $0 \mathrm{~b}$ & $0 \mathrm{~b}$ & $14.0 \mathrm{~b}$ & $11.0 \mathrm{~b}$ & $33.0 \mathrm{a}$ & $0 b$ & $0 \mathrm{~b}$ \\
\hline & Machaerium inundatum (2) & $104.4 \mathrm{a}$ & $69.2 \mathrm{a}$ & $97.6 \mathrm{a}$ & $5.0 \mathrm{~b}$ & $3.0 \mathrm{~b}$ & $48.4 \mathrm{a}$ & $35.0 \mathrm{a}$ & $62.0 \mathrm{a}$ & $6.0 \mathrm{~b}$ & $4.0 \mathrm{~b}$ \\
\hline & Machaerium quinata & $4.6 a$ & $0 \mathrm{a}$ & $11.6 \mathrm{a}$ & $0 \mathrm{a}$ & $0 \mathrm{a}$ & $6.0 \mathrm{a}$ & $0 \mathrm{a}$ & $10.0 \mathrm{a}$ & $0 \mathrm{a}$ & $0 \mathrm{a}$ \\
\hline & TOTAL & 230.8 & 241.1 & 247.9 & 18.8 & 50.0 & 185.4 & 326.0 & 195.0 & 48.0 & 118.0 \\
\hline & $\%$ nodulated species & 100 & 78 & 100 & 44 & 55 & & & & & \\
\hline
\end{tabular}

${ }^{(1)}$ Means of five plants. Means with the same letter in the same line do not significantly differ, according to the Skott-Knott test, at 5\%. 
Table 4. Identification by means of the 16S rRNA partial sequences of strains isolated from nodules of the scandent legume species native from Amazonia, after growth in five substrates in nursery. SAND, washed sand with mixed inoculum of 100 rhizobia strains plus fertilization; HG, A-horizon of Humic Gley soil collected in the floodplain of Solimões River; CONV, conventional substrate of nursery, consisting of a clay and sand mixture, in a ratio 3:2 (v:v); ULT, A-horizon of red-yellow Ultisol collected in the Ducke Forest Reserve (Manaus); and ULTfert, fertilized ULT substrate. Pb - base pairs.

\begin{tabular}{|c|c|c|c|c|c|c|c|}
\hline \multirow[b]{2}{*}{ Strains } & \multirow{2}{*}{$\begin{array}{c}\text { Strain GenBank } \\
\text { Acession number }\end{array}$} & \multirow[b]{2}{*}{ Scandent Legumes } & \multirow[b]{2}{*}{ Substrate } & \multirow{2}{*}{$\begin{array}{c}\text { Extension } \\
(\mathrm{pb})\end{array}$} & \multicolumn{3}{|c|}{ GenBank sequences similarities } \\
\hline & & & & & Species & $\begin{array}{c}\text { Accession } \\
\text { number }\end{array}$ & $\begin{array}{c}\text { Similarity } \\
\%\end{array}$ \\
\hline INPA01-445A & KT826553 & Dalbergia inundata Spruce ex Benth. & SAND & 616 & Brevibacillus sp. & FJ719350.1 & 99 \\
\hline INPA01-447A & KT826555 & Dalbergia inundata Spruce ex Benth. & $H G$ & 717 & Bradyrhizobium sp. & KC677617.1 & 99 \\
\hline INPA01-446A & KT826554 & Dalbergia inundata Spruce ex Benth. & SAND & 805 & $\begin{array}{l}\text { Burkholderia } \\
\text { fungorum }\end{array}$ & GU144371.1 & 99 \\
\hline INPA01-475A & KT826556 & Dalbergia riedelii (Benth.) Sandwith. & $H G$ & 681 & Bradyrhizobium sp. & KJ739927.1 & 100 \\
\hline INPA01-481B & KT826558 & Dalbergia riedelii (Benth.) Sandwith. & ULTfert & 587 & Bradyrhizobium sp. & KF933595.1 & 99 \\
\hline INPA01-477B & KT826557 & Dalbergia riedelii (Benth.) Sandwith. & ULT & 365 & Brevibacillus sp. & FJ719350.1 & 99 \\
\hline INPA01-485A & KT826560 & Dalbergia riparia (Mart. ex Benth.) Benth. & SAND & 641 & Bradyrhizobium sp. & KF483532.1 & 99 \\
\hline INPA01-485B & KT826561 & Dalbergia riparia (Mart. ex Benth.) Benth. & SAND & 635 & Bradyrhizobium sp. & KJ739927.1 & 99 \\
\hline INPA01-486B & KT826562 & Dalbergia riparia (Mart. ex Benth.) Benth. & $H G$ & 666 & Bradyrhizobium sp. & KC247114.1 & 98 \\
\hline INPA01-488A & KT826564 & Dalbergia riparia (Mart. ex Benth.) Benth. & ULT & 594 & Bradyrhizobium sp. & KJ739927.1 & 100 \\
\hline INPA01-482B & KT826559 & Dalbergia riparia (Mart. ex Benth.) Benth. & SAND & 795 & Bradyrhizobium sp. & FJ390909.1 & 100 \\
\hline INPA01-487A & KT826563 & Dalbergia riparia (Mart. ex Benth.) Benth. & $H G$ & 593 & Enterobacter sp. & KR190062.1 & 99 \\
\hline INPA01-514A & KT826566 & Machaerium quinata (Aubl.) Sandwith. & SAND & 275 & Bradyrhizobium sp. & JX514888.1 & 100 \\
\hline INPA01-519B & KT826567 & Machaerium inundatum (Mart. Ex. Benth.) & $H G$ & 786 & Bradyrhizobium sp. & KJ658657.1 & 99 \\
\hline INPA01-521A & KT826568 & Machaerium inundatum (Mart. Ex. Benth.) & ULTfert & 267 & Bradyrhizobium sp. & JX514888.1 & 100 \\
\hline INPA01-610A & KT826569 & Deguelia negrensis Benth. & SAND & 463 & Bradyrhizobium sp. & KC247113.1 & 99 \\
\hline INPA01-510A & KT826565 & Deguelia negrensis Benth. & ULTfert & 841 & Bradyrhizobium sp. & FJ025100.2 & 100 \\
\hline
\end{tabular}

\section{DISCUSSION}

The high survival percentage of seedlings after transplanting of all species is a good feature for their management, indicating lack of dormancy. However, most of them must be sown as soon as possible after collection (Silva et al. 1988; Moreira et al. 1992; Moreira and Moreira 1996) because they rapidly lost their viability.

In general, the different parameters of growth for the species: Mimosa sp., Dalbergia inundata, Dalbergia riparia and Machaerium inundatum, exhibited higher values in the substrates of higher fertility- HG and ULTfert (Tables 1 and 2 ), indicating these species are not oligotrophic. This feature can have important implications in the ecology of these species as well as their possible management for economic purposes. For instance, it could imply that their cultivation requires fertilization either organic or mineral.

It should be highlighted that the other species: Entada polystachya, Dalbergia riedelii, Deguelia negrensis and Machaerium quinata had no differences in all growth parameters among substrates probably because, except Dalbergia riedelii, they grew less than the other species, which was indicated by their growth class (height) measured at five months. The root/shoot ratio was usually lower than 1 in all substrates and for all species, except for Entada polystachya, corroborating these species are not adapted to oligotrophic conditions, where usually larger root systems enable plants to take up more nutrients.

Large differences of growth were observed between the two provenances of Dalbergia riparia. On the other hand only slight differences were observed between the two provenances of Machaerium inundatum (Table 1). Different seed physiological maturation points (Moreira and Moreira 1996), or genetic and phenotypic variability between matrices individuals (provenances) may provide differences in the species' growth. For instance, Entada polystachya, which reached about $150 \mathrm{~cm}$ tall in previous work, from seeds collected in fertile soil of floodplain (Moreira 1995), did not exceed $30 \mathrm{~cm}$ in this work, with seeds from matrix found in dry land ("terra firme") with low fertility.

Nodulation capability did not influence the growth class (Tables 1 and 3), i.e., it did not promote better growth (highest height) of species, since all growth classes were found among nodulating species. The response of nodulation of scandent species to different substrates was similar to the response of several native tree species reported by Moreira $(1995 ; 1997)$, i.e., nodulation was greater in SAND, HG and CONV than in ULT and ULTfert substrates.

Despite the high number of strains inoculated in SAND, competition for infection sites was not a limiting factor in the nodulation of the studied species. Although most strains 
isolated from SAND were identified as Bradyrhizobium, one Burkholderia strain was also isolated from Dalbergia inudata. For sure this strain was included in the mix of the inoculants and it was reisolated. On the other hand, the absence of nodulation in Deguelia negrensis and Machaerium quinata in HG substrate; in Dalbergia riparia (provenance 1 e 2), Machaerium inundatum (provenance 1) and Machaerium quinata in ULT and ULTfert substrates; and in Deguelia negrensis in ULT substrate means that there are limiting factors for nodulation in these substrates, which may include: the absence of specific rhizobia strains; physical factors, such as reduced aeration in HG substrate, due to inherent high clay content; and/or chemical factors, such as the high Al content in ULT substate (Moreira 2006). Thus, further studies for cultivation of these species in these substrates should consider these factors.

The prevalence of strains belonging to Bradyrhizobium genus is related to the high frequency of isolates of intermediate to slow growth, and to alkaline reaction in medium 79, which are important characteristics of the genus (Jordan 1982). These results corroborate with Moreira et al. (1993), who identified Bradyrhizobium by total protein profile (SDS-PAGE) in symbiotic strains of Entada polystachya var. polyphylla, Dalbergia riparia, Machaerium inundatum and Deguelia negrensis.

Other strains of Deguelia negrensis (INPA01-609A) and Machaerium quinata (INPA01-514A), derived from the same capture experiment in a greenhouse, also had the $16 \mathrm{~S}$ rRNA gene previously sequenced and identified as Bradyrbizobium (Moreira et al. 1998). For Dalbergia riedelli and Dalbergia inundata, this is the first report on the identification of symbiotic strains.

Bacteria of the Bradyrbizobium genus are widely known for their ability of nodulation and biological nitrogen fixation in legume species. Studies have shown the presence of this genus with high genetic and phenotypic diversity in Amazonian soils, and with variable efficiency of nitrogen fixation with different hosts (Moreira et al. 1993; Lima et al. 2005; Guimarães et al. 2012; 2015). The high genetic stability of this genus is well known (Moreira 2006) and it confers an important feature to the symbiosis with these scandent legumes species.

Strains of Brevibacillus and Enterobacter genera were isolated from nodules of two liana species (Dalbergia inundata and Dalbergia riparia) but these genera are not yet recognized as nodulating symbiotic bacteria. However, these and other genera are usually recongnized as endophytic bacteria in nodules (Kan et al. 2007; Jaramillo et al. 2013; Oliveira-Longatti et al. 2013). which can act as plant growth promoters by the production of indoleacetic acid, siderophores, and by phosphate solubilization (Chen et al. 2006; Marra et al. 2012). Indeed, enhancement of plant growth by Brevibacillus sp. (Vivas et al. 2003; Jha and Saraf 2012) and Enterobacter (Kan et al. 2007; Aserse et al. 2013; Costa et al. 2013) has been demonstrated.

Some species of the Burkholderia genus were proven to be capable of establishing symbiosis with legume species, and are considered as beta-rhizobia (Moulin et al. 2001; Elliott et al. 2007). Burkholderia fungorum strains showed efficiency in nitrogen fixation in free-living conditions, and calcium phosphate and aluminum solubilization (OliveiraLongatti et al. 2013; 2014) and also were proved to present nodulation ability in Phaseolus vulgaris (Ferreira et al. 2012). The symbiosis of Burkholderia fungorum with Dalbergia inundata found in this work expands the knowledge on the capacity of beta-rhizobia to nodulate legumes from the subfamily Papilionoideae

\section{CONCLUSIONS}

All the legume scandent species studied presented high survival percentage after transplanting of seedlings to nursery and all the substrates were suitable for the development of the studied species. Besides, higher growth of four species were found in substrates with high fertility (HG and ULTfert) and the growth of other four species was similar among substrates. Nodulation was highest when rhizobia was introduced (SAND substrate) and with native rhizobia of CONV substrate, followed by HG substrate. Symbiosis with rhizobia in all the nodulating species is predominantly performed with strains of the Bradyrhizobium genus. Exception was the Burkholderia fungorum strain INPA01-446A as a symbiont of Dalbergia inundata. These features can have important implications in the ecology of these species as well as they can be useful in their possible management for economic purposes.

\section{ACKNOWLEDGEMENTS}

We thank the Financiadora de Estudos e Projetos (FINEP) and Fundaçáo de Amparo à Pesquisa do estado de Minas Gerais (FAPEMIG) for financial support. The Fundação de Amparo à Pesquisa e ao Desenvolvimento Científico e Tenológico do Maranhão (FAPEMA) and Coordenaçấo de Aperfeiçoamento de Pessoal de Nível Superior (CAPES) for scholarships. We also thank the Conselho Nacional de Desenvolvimento Científico e Tecnológico (CNPq) for research productivity fellowship and Francisco Wessen Moreira, Valderico Cabral Wessen and José Olegário Silva Filho for valuable helping in nursery and field work.

\section{REFERENCES}

Aserse, A.A.; Räsänen, L.A.; Aseffa, F.; Hailemariam, A.; Lindström, K. 2013. Diversity of sporadic symbionts and nonsymbiotic endophytic bacteria isolated from nodules of woody, shrub, and food legumes in Ethiopia. Applied Microbiology and Biotechnology, 97:10117-10134. 
Braz Filho, R.; Almeida, M.E.L.; Gottlieb, O.R. 1973. Iso- and Neoflavonoids from Dalbergia riparia. Phytochemistry, 12:1187-1188.

Chen, Y.P.; Rekha, P.D.; Arun, A.B.; Shen, F.T.; Lai, W.A.; Young, C.C. 2006. Phosphate solubilizing bacteria from subtropical soil and their tricalcium phosphate solubilizing abilities. Applied Soil Ecology, 34:33-41.

Costa, E.M.; Nóbrega, R.S.A.; Carvalho, F.; Trochmann, A.; Ferreira, L.V.M.; Moreira, F.M.S. 2013. Plant growth promotion and genetic diversity of bacteria isolated from cowpea nodules. Pesquisa Agropecuária Brasileira, 48:1275-1284.

Dilworth, M.J. 1966. Acetylene reduction by nitrogen-fixing preparations from Clostridium pasteurianum. Biochimica et Biophysica Acta, 127:285-294.

Ducke, A. 1949. Notas sobre a flora neotrópica. II. As leguminosas da Amazônia Brasileira. Boletim Técnico 18 do Instituto Agrônomico do Norte, Belém, 248p.

Elliott, G.N.; Chen, W.M.; Bontemps, C.; Chou, J.H.; Young, J.P.W.; Sprent, J.I.; James, E.K. 2007. Nodulation of Cyclopia spp. (Leguminosae, Papilionoideae) by Burkholderia tuberum. Annals of Botany, 100:1403-1411.

Ferreira, D.F. 2011. Sisvar: a computer statistical analysis system. Ciência e Agrotecnologia, 35:1039-1042.

Ferreira, P.A.A.; Bomfeti, C.A.; Soares, B.L.; Moreira, F.M.S. 2012. Efficient nitrogen-fixing Rhizobium strains isolated from amazonian soils are highly tolerant to acidity and aluminium. World Journal of Microbiology and Biotechnology, 28:1947-1959.

Franco, A.A.; Faria, S.M. 1997. The contribution of $\mathrm{N}_{2}$-fixing tree legumes to land reclamation and sustainability in the tropics. Soil Biology and Biochemistry, 29:897-903.

Fred, E.B.; Wasksman, S.A. 1928. Laboratory manual of general microbiology - with special reference to the microorganisms of the soil. McGraw-Hill Book Company, New York, 168p.

Grauel, W.T.; Putz, F.E. 2004. Effects of lianas on growth and regeneration of Prioria copaifera in Darien, Panama. Forest Ecology and Management, 190:99-108.

Guimarães, A.A.; Jaramillo, P.M.D.; Nóbrega, R.S.A.; Florentino, L.A.; Silva, K.B.; Moreira, F.M.S. 2012. Genetic and Symbiotic Diversity of Nitrogen-Fixing Bacteria Isolated from Agricultural Soils in the Western Amazon by Using Cowpea as the Trap Plant. Applied and Environmental Microbiology, 78:6726-6733.

Guimarães, A.A.; Florentino, L.A.; Almeida, K.A.; Lebbe, L.; Silva, K.B.; Willems, A.; Moreira, F.M.S. 2015. High diversity of Bradyrhizobium strains isolated from several legume species and land uses in Brazilian tropical ecosystems. Systematic and Applied Microbiology, 38:433-441.

Jaramillo, P.M.D.; Guimarães, A.A.; Florentino, L.A.; Silva, K.B.; Nobrega, R.S.A.; Moreira, F.M.S. 2013. Symbiotic nitrogenfixing bacterial populations trapped from soils under agroforestry systems in the Western Amazon. Scientia Agricola, 70:397-404.

Jha, C.; Saraf, M. 2012. Evaluation of Multispecies Plant-GrowthPromoting Consortia for the Growth Promotion of Jatropha curcas L. Journal of Plant Growth Regulation, 31:588-598.

Jordan, D.C. 1982. Transfer of Rhizobium japonicum Buchanan 1980 to Bradyrhizobium gen. nov., a Genus of Slow-Growing, Root
Nodule Bacteria from Leguminous Plants. International Journal of Systematic Bacteriology, 32:136-139.

Kan, F.L.; Yichen, Z.; Wang, E.T.; Tian, C.F.; Sui, X.H.; Chen, W.X. 2007. Characterization of symbiotic and endophytic bacteria isolated from root nodules of herbaceous legumes grown in Qinghai-Tibet plateau and in other zones of China. Archives of Microbiology, 188:103-115.

Lane, D.J. 1991. 16S/23S rRNA sequencing, In: Stackebrandt, E.; Goodfellow, M. (Ed). Nucleic acid techniques in bacterial systematics. John Wiley e Sons Inc, New York, p.115-175.

Lima, A.S.; Pereira, J.P.A.R.; Moreira, F.M.S. 2005. Phenotypic diversity and symbiotic efficiency of Bradyrhizobium spp. Strains from Amazonian soils. Pesquisa Agropecuária Brasileira, 40:1095-1104.

Marra, L.M.; Soares, C.R.F.S.; Oliveira, S.M.; Ferreira, P.A.A.; Soares, B.L.; Carvalho, R.F.; Lima, J.M.; Moreira, F.M.S. 2012. Biological nitrogen fixation and phosphate solubilization by bacteria isolated from tropical soils. Plant and Soil, 357:289-307.

Moreira, F.M.S.; Gillis, M.; Pot, B.; Kersters, K.; Franco, A.A. 1993. Characterization of rhizobia isolated from different divergence groups of tropical Leguminosae by comparative polyacrylamide gel electrophoresis of their total proteins. Systematic and Applied Microbiology, 16:135-146.

Moreira, F.M.S.; Silva, M.F.; Faria, S.M. 1992. Occurrence of nodulation in legume species in the Amazon region of Bazil. New Phytologist, 121:563-570.

Moreira, F.M.S. 1995. Nodulação e crescimento de leguminosas em dois solos da Amazônia. Revista Brasileira de Ciência do Solo, 19:197-204.

Moreira, F.M.S.; Moreira, F.W. 1996. Nursery germination and seedling characteristics of sixty four legume species native in the Amazon Forest. Acta Amazônica, 26:3-16.

Moreira, F.M.S. 1997. Nursery growth and nodulation of forty-nine woody legume species native from Amazonia. Revista Brasileira de Ciência do Solo, 21:581-590.

Moreira, F.M.S.; Haukka, K.; Young, J.P.W. 1998. Biodiversity of rhizobia isolated from a wide range of forest legumes in Brazil. Molecular Ecology, 7:889-895.

Moreira, F.M.S. 2006. Nitrogen-fixing Leguminosae-nodulating bacteria. In: Moreira, F.M.S.; Siqueira, J.O.; Brussaard, L. (Ed). Soil biodiversity in Amazonian and other Brazilian ecosystems. CAB International, Wallingford. United Kingdom, p.237-270.

Moulin, L.; Munive, A.; Dreyfus, B.; Boivin-Masson, C. 2001. Nodulation of legumes by members of the $\beta$-subclass of Proteobacteria. Nature, 411:948-950.

Niemann, S.; Puehler, A.; Tichy, H.V.; Simon, R.; Selbitshka, W. 1997. Evaluation of the resolving power of three different DNA fingerprinting methods to discriminate among isolates of a natural Rhizobium meliloti population. Journal of Applied Microbiology, 82:477-484.

Oliveira-Longatti, S.M.; Marra, L.M.; Moreira, F.M.S. 2013. Evaluation of plant growth-promoting traits of Burkholderia and Rhizobium strains isolated from Amazon soils for their co- 
inoculation in common bean. African Journal of Microbiology Research, 7:948-959.

Oliveira-Longatti, S.M.; Marra, L.M.; Soares, B.L.; Bomfeti, C.A.; Silva, K.; Ferreira, P.A.A.; Moreira, F.M.S. 2014. Bacteria isolated from soils of the western Amazon and from rehabilitated bauxitemining areas have potential as plant growth promoters. World Journal of Microbiology and Biotechnology, 30:1239-1250.

Ribeiro, M.N.S.; Zoghbi, M.G.B.; Silva, M.L.; Gottlieb, O.R.; Rezende, C.M.M. 1987. Cadastro fitoquimico brasileiro. INPA/ FUA, Manaus, 112p.

Schnitzer, S.A.; Dalling, J.W.; Carson, W.P. 2000. The impact of lianas on tree regeneration in tropical forest canopy gaps: evidence for an alternative pathway of gap-phase regeneration. Journal of Ecology, 88:655-666.

Schnitzer, S.A.; Parren, M.P.E.; Bongers, F. 2004. Recruitment of lianas into logging gaps and the effects of pre-harvest climber cutting in a lowland Forest in Cameroon. Forest Ecology Management, 190:87-98.
Silva, M.F.; Goldman, G.H.; Magalhães, F.M.M.; Moreira, F.W. 1988. Germinação natural de 10 leguminosas arbóreas da Amazônia I. Acta Amazonica, 18:9-26.

Vincent, J.M. 1970. A manual for practical study of the root nodule bacteria. Blackwell Scientific Publications, Oxford, 164p.

Vivas, A.; Vörös, A.; Biró, B.; Barea, J.M.; Ruiz-Lozano, J.M.; Azcón, R. 2003. Beneficial effects of indigenous Cd-tolerant and Cd-sensitive Glomus mosseae associated with a Cd-adapted strain of Brevibacillus sp. in improving plant tolerance to $\mathrm{Cd}$ contamination. Appied Soil Ecology, 24:177-186.

Zoghbi, M.G.B.; Silva, M.L.; Cabral, J.A.S. 1992. INPAs Phytochemical Catalog. MCT/INPA, Manaus, 57p.

Recebido em 18/02/2016

Aceito em 05/05/2016 
